DOI: $10.21625 /$ archive.v2i2.247

\title{
ETHNOMUSICAL STUDY ON THE ANCESTRAL SOUND PRODUCED BY CAPOLIN
}

\author{
Maria Fernanda Viteri ${ }^{1}$, Maria Cristina Paez Quinde ${ }^{1}$, Victor Hernandez del Salto ${ }^{1}$, Ana \\ del Rocio Silva Mayorga ${ }^{1}$, Ruth Elizabeth Infante ${ }^{1}$, Francisco Torres Oñate ${ }^{1}$ \\ ${ }^{1}$ Facultad de Ciencias Humanas y de la Educación, Universidad Técnica de Ambato
}

\section{Keywords}

capolin, leaf, ancestral sound, tourism

\begin{abstract}
The spontaneous and traditional art represents one of the most important aspects in the culture of a town because it is the worldview manifestation that shows cultural reality in areas that are considered socially subaltern. This is the case of the Ecuadorian Andean region, where the ancestral sound of capolin leaves shows a historical experience and a particular sensitivity. Capolin is a leafy tree native from America. It has simple, alternate, oblongo laceolate leaves that are 6 to $14 \mathrm{~cm}$ long by 2 to $4 \mathrm{~cm}$ wide. It has 3 to 5 prominent nerves from the base of the leaf. This musical technique is part of the Ecuadorian culture and has been inherited and transmitted from a remote past and at the same time is a resource with high cultural vulnerability. When talking about the research work it is worth adding that a descriptive study was carried out. It encompasses the representative cultural features of the plant in the population and the fundamental dendrolgical characteristics. The study also goes through the frecuency and the decibels created by the sound of the plant, the intonation and the human effect caused by this sound. The research concludes that the transversal axis of music is creativity and that boosting this type of manifestations can be a motivation for the dynamization of the touristic activity because it is part of the intangible heritage of a town.
\end{abstract}

\section{Introduction}

\section{Ethnomusic and ancestral sound}

Ethnomusic forms part of musicology and it is defined as the musical study of cultures' oral traditions. The object of study of ethnomusicology is traditional music and instruments of all mankind cultures (Morales de la Mora, 2003). The musical phenomenon allows to have a better communication among human population, but the most important thing is that music creates a sense harmony among peoples in a social context. In addition, it becomes an observer component of intercultural dialogue, which is aimed to individualise with the group of sounds like harmony, rythm, melody and tonal coherence (Cámara de Landa, 2010). It eases coexistence, learning and a town or population enrichment (Carvalho, 2003).

Ethnomusic represents the person both socially and culturally, as an interpretation aimed at focusing on important circumstances such as festivals and rituals. It is also a musical expression that belongs to oral tradition and it allows to obtain musical imagination of the product found in the place (Artez \& Felipe, s/f). It interacts directly with traditional musical instruments. The network of practitioners and music producers that make possible the deep study of the musical genre have found traces and paintings, sacred places, drawings among others.

The ancestral sound is an interpretation performed with different musical instruments. They emit a gentle musical rhythm for ears. At the same time, there is a sense of contact with nature. These ancestral sounds are heard more frequently in indigenous areas since these keep a linked to the countryside lifestyle. That is why (Fernández, 2010) 
the ancestral sound is a state of contact with unknown cultures. In the Andean world, music is an important factor that reflects the relationship between the person and the different spiritual, ritual, cultural, natural and ceremonial expressions. It makes the person aware of the interaction between environment and his or her habitat (Castillo, 2015).

Within nature it is very common to hear sounds of animals and their environment (bird whistle, wind, water, rain, trees among others). During ages, humans have learned to imitate and polish them by combining the sounds with rhythm created with other instruments. These musical expressions show indigenous ways of living both in their present and their past (Benítez, Albuja, \& Vaca, 2016). This encourages the community to have values like solidarity, friendship, and strength, which creates people from the community integration.

The ancestral sound is considered as a means of communitarian communication (Peña, 2012). People from the communities used it to show that there are problems into the community. They organize meetings and team work in order to defend the peoples' wholeness.

The interpretation of traditional music has become a form of identity resistance that characterizes and defines indigenous people. At the same time, it constitutes a strong bond with the past because it is closely linked to it. This was a historical time with a completely different way of living that the current times (Flores, 2009). Both the ethnomusic and the ancestral sound are part of the intangible heritage since they include representations, expressions, techniques, and cultural spaces that are congenital to a community (Olivera, 2011). They have aesthetic value that characterizes a community (Asiáin \& Aznárez, 2012). It also contributes to tourism in a significant way because it generates interest in the market. Most tourists like to know different ways of living, so they would like to be part of them.

\section{Capolin}

The tree that is called Prunus Serotina subsp. capolin (Cav.), is a monopodic, evergreen, or deciduous or shrub tree that grows from 5 to $15 \mathrm{~m}$. of height, and in some cases up to $38 \mathrm{~m}$. They are distributed from the south of Canada to the south of Bolivia (McVaugh, 1951). The anatomy varies, the most common tree has got a long and straight trunk in forests, whereas in temperated zones it is short and wide with alternating branches. Their leaves are characterized by being stipulated, simple, alternate, shortly petiolate, and ovate alanceolate that measure 5 to 16 $\mathrm{cm}$. of length and 2 to $5 \mathrm{~cm}$. of width. It has brown and gray bark almost smooth and glabrous, its numerous small and white flowers are grouped in auxiliary long clusters. Its fruit is a globular drupe of reddish-black color, which in the maturity gets a bittersweet flavor. It contains a single seed (Fresnedo-Ramírez, Segura, \& Muratalla-Lúa, 2011). The particularity of this plant is that it is not necessary to sow it with men's hand, but it grows independently. They are conserved by farmers because of their fruit and wood price. Its leaves and flowers are used for therapeutic purposes due to the fact that it helps to improve respiratory diseases (Lozoya, 1982). The capolin fruit is used to make sweet and liquid products, while its wood is appreciated because of its strength and durability. It was used in the Colony to manufacture pianos.

Each part of the capolin tree has a goal in different fields such as: medicine, commerce, food, animal building or animal fodder (Avendaño-Gómez, y otros, 2015). In medicine, it is used to treat respiratory and nervous diseases. In addition, it is used as an insecticide in different communities of Latin America (McVaugh, 1951). In addition, capolin dry leaves are boiled and used as a cardiorregulator for the treatment of cutaneous infections. The cortex is used as antirheumatic medicine to treat wounds and bruises (Agapito \& Sung, 2005). Furthermore, in traditional medicine this plant leaves are used to treat diuretic and expectorant diseases as well as to deal with sleepless, diarrea, fever and digestive problems (Mantilla, 2004). Infusions made from their leaves and bark have medicinal properties such as antibacterials and antioxidants useful for respiratory diseases (Jiménez, Castillo, Azuara, \& Beristain, 2011). A phytochemical study of capolin leaves identified relaxing compounds that smooth the muscle. Simultaneously, capolin essential oil was investigated to verify its displacement as a vascular relaxant and thus to verify that it contributes to human health as a treatment against hypertension (Ibarra at all, 2009, págs. 165-171). Mixtures with chemicals and capolin leaf are also made to obtain ointments or medicines that are used to relieve gastrointestinal problems (Rivero-Cruz, 2014). Something similar happens when chemical components are combined with the plant. For example, it in combination with hyperoside and chlorogenic acid have protective effects to improve cardiac functions and relieve pain. Additionally, (Hernández-Rodríguez, y otros, 2016). It was found that capolin leaves are excellent antioxidant sources just like capolin seed that contains highly polyunsaturated fatty acids with omega 3 and omega 6 , which are essential for human beings. Within indigenous communities, leaves are used as musical instruments to create sounds similar to the ones birds do by placing the leaf in the mouth to blow. This technique was practiced by the native peoples, but it currently performed in rituals 
like an expression of hubbub. In this way it can be confirmed that the capolin leaves have multiple usages in human beings life.

\section{State of Art}

The following topics are essentialaccording to selected documents: popular music, identity, resistance, methodological tools, cultural fact, human development, everyday spaces, music anthropology, role of music in the construction of identity, creativity, holidays and sociological proposal. The related fields of inquiry are based on conceptions that raise questions and establish mental processes that allow music production as a cog in the social and cultural context. With an anthropological perspective, identities and semiotic configurations could be determined, which could make an ethnomusicological study the discovery of a socio-cultural fact with its own logics and dynamics (González de Pérez., 2005) "Sobre el estudio de la música como hecho cultural", claims that musical conceptions must raise questions that talk about mental processes and worldviews. The interest of music study lies on its social and cultural context. And in our society, what conception do we have of music, musicians, composers, and interpreters? Does each type of music, each instrument, deserve equal opinions? However, there is a weakness in this research: the most empirical measurement tools.

The sociocultural function of ancestral music, a material and sound support, often involves an extra dimension determined by the functional and symbolic role it plays in society (Dorunon, 1981) "Guía para recolectar instrumentos musicales tradicionales", determines the importance of musical instruments in cultural heritage because it asserts that when traveling, it is surprising to discover, by consulting specialized works or visiting the rooms and reserves of a museum, to what extent the scope of the musical instruments is rich and diverse. At the same time, recommendations and working tools have been proposed so that the collection of the musical material is carried out reasonably and efficiently, without causing harm to the community that owns it. The desing of research collection tools contributes to the investigation.

The social senses that are provoked in the musical listener, construct the sociomusical spaces with the capacity of resignification of the sympathizers and the possibility of generating own and differentiated collective practices (Ramírez, 2012) “¿Identidades sociomusicales rurales?” Poses formation process of sociomusical identities, with acoustic structures typical of the musical genre. The social imaginary to which it appeals conforms the specific characteristics of the particular context in which listeners receive music in one way or another. Therefore, it is possible to find the conducting threads between ancestry, biology and social production of music in the capolin leaf.

The most significant contribution of ethnomusical research is that concepts do not exist in music (Jardow-Pedersen, 2003) "El MANUAL DE ETNOMUSICOLOGÍA HISTORIA, RECOPILACION, INSTRUMENTOS, TRANSCRIPCION, SIGNFICADO”, designs the third communicative dimension that consists of messages and meanings that music generates, attributable qualities and incidents in listeners, consciously or unconsciously make them part of that culture represented in harmonic sounds. The main contribution of ethnomusical research is to rethink the ethnomusicologist researcher technical condition, until becoming someone who can transform intercultural processes to intracultural nature (Nettl, 2003) "Reflexiones sobre el siglo XX: el estudio de los "Otros" $\mathrm{y}$ de nosotros como etnomusicólogos confers on ethnomusicology a fundamental role in the study of the "other musical," then the transition to the "other" culture makes the researcher an active subject of that culture.

The participation of environmental sounds exposes a social change, with the desacralization of certain areas of life in exchange for the sacralization of others (Martí J. , 2009) “Como el aire que respiramos: músicas ambientales en espacios de la cotidianidad", Proposes with his research the desacralization of the glorified world-music, then the ancestral music could be measured by using western quantitative forms.

Music is a means of symbolic communication, capable of expressing the repressed desires in the unconscious, and it is capable of creating responses where, it is assumed, all sorts of thoughts, both rational and irrational (Steingress, 2006) "El caos creativo: fiesta y música como objetos des deconstrucción y hermenéutica profunda, una propuesta sociológica", expresses the ambiguity of the humans as social and natural beings. Expressive forms act in the process of collective renegotiation towards the relationship between nature and human culture. This is between the individual and society as factors of sublimation and desublimation, repression and liberation.

Artistic production has unsuspected qualities, capable of activating individual and collective self-esteem, as well as strengthening of social and territorial ties (Londoño, 2008). "Memoria colectiva y músicas locales en una

de desarrollo humano", concludes that it is possible to claim: taking care, giving value and re-creating local, rural and urban songs is assuming them as a collective memory and take advantage of them because they are unique cultural heritage. In addition, it opens possibilities for individual and community human development. This 
encourages the intergenerational communication, and the growth of a historical consciousness like factors of tourist promotion.

Music has assimilated a wide range of changes and mutations that go through the introduction of new languages, communication and listening habits alteration. Therefore, it is a crisis of traditional aesthetic canons from notions of art itself (Hormigos, 2010) "La creación de identidades culturales a través del sonido", states that the history of western music in the last fifty years was marked by its integration into a society, in which the predominant form of diffusion of culture is mass media and new technologies.

The fact of knowing minority music types that belong to another time or space expands the range of alternatives and stimulates the end of that homogeneity (Rodríguez, 2015) "El papel de la música en la construcción de una identidad durante la adolescencia ¿Dime qué escuchas y te diré quién eres?”, establishes that the adolescent is the sole owner and responsible for their choices within the framework of diversity in order to analyze which elements intervene in the musical phenomenon from different points of view. It helps to understand that in addition to a very important cultural manifestation, it is also the product of business.

The discussion on popular music often resorts to the appeal or the simple acceptance or not of the public and renunciation of judgment and evaluation (Alabarces, 2008) "Posludio: Música popular, identidad, resistencia y tanto ruido (para tan poca furia)" It recovers the dimension of aesthetic valuation beyond a relativist concept, because the diversity of aesthetics can converge into political concepts. The ability to value biological, social and cultural diversity goes hand in hand with the advancement of thought models based on a socio-environmental conscience that promotes intra and intergenerational social solidarity, respect for heterogeneity and harmony with the environment (Cergio, 2002) on his work "El imaginario sonoro de los tiempos", leaves the vacuum of a methodology of analysis, as part of the experiences from the Experimental Orchestra of Andean instruments musical performance. Dimensions focus on subjectivity with the following categories: reincarnation, growth, longing and illusion. The aspects that need to be addressed in the analytical discourse are: theoretical discussion and measurement tools.

Musical research, besides penetrating the abstractions of thought, also tries to find the unprecedented and enduring precisions of spirit (Veladiz) shows that "Musicoterapia con instrumentos de origen precolombino", there isn't a theoretical reference, It is argued in favor of a Music Therapy Diploma, with a duration of 206 hours along 13 modules. It remains as a pending aspect of an approach to an intercultural dialogue that allows to lower the emotional levels produced by urban everyday life. The objective of ancestral music research is to situate, through a multidisciplinary analysis that includes an organological, anthropological and acoustic description (Fabre, de la Cuadra, \& Pérez de Arce, 2012). In the article "Antaras Aconcagua: un estudio antropológico y acústico", there is a lack of acoustic measurement instruments, and the features of the instrument and the rites that accompanied it, in an attempt to rescue the memory of who was a central icon of Aconcagua culture. A pending element in the methodology is an in-depth interview to the musical instrument performer. It will be a fundamental element in the configuration of the peoples' cultural heritage, which in the case of the present research, is an added value for tourism.

\section{Methodology}

For the present study, an ethnographic research on the resulting ethnomusic sound resulting from the capolin leaf (typical practice in the Ecuadorian Andean reagion). In order to study this sample, music transcription along with musical and sound features measurement were applied. When a body or system reaches the maximum degree of oscillation, we speak of resonance frequency. We take as a reference the principle by which every body or system has one or more characteristic frequencies. The increase of vibration occurs because of resonance. In order to determine the intensity generated by the sound. SPL were measured by $(\mathrm{dB})$ and it will vary between $0 \mathrm{~dB}$ threshold of hearing and $120 \mathrm{~dB}$ threshold of pain. The calculation of sound pressure levels (SPL $\mathrm{dB}$ ) should be guided by the average of frequencies, and the formula to be used is:

$$
\$\left(\&^{\prime}\right)=10 \log \quad\left[\sum_{563}^{\&} 10{ }_{34}^{\underline{012}}\right]
$$

The average values are analyzed by the free software; Pacalculate, which studies the sound pressure level (SPL $\mathrm{dB}$ ). In order to analyze the rhythmic and tonal features of the melody, major and minor scales were used. In addition, chords we added according to the tonality 


\section{Results}

The capolin leaf vibrates when it is handled by the ends and the musician blows. The conversion from blow to sound is produced due to the excitement point that reaches the leaf. The level of the sound wave is directly related to the pressure exerted on the blade, the more energetic it blows, the sharper and stronger the sound it emits. In the experimentation the maximum frequency reached by capolin sheet when receiving pressure had an average of 6122 Hz with an amplitude of $-5.9 \mathrm{~dB}$.

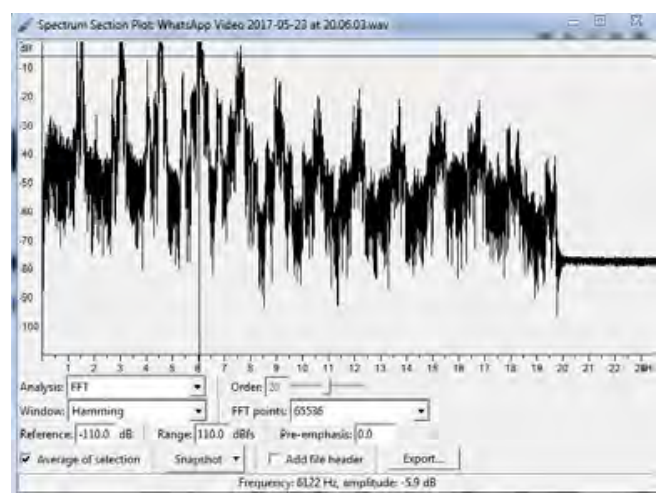

Figure 1

In the left part of the table we can appreciate the change of $\mathrm{dB}$ and in the lower part the frequency change measured in Hz. Bearing in mind that the sound is not pure, which means it does not have the characteristic of being simple sinusoidal because of the harmonics presence, it is concluded that in the fundamental frequency, the noises are represented by the grass in the graph and harmonics are represented after each high peak.

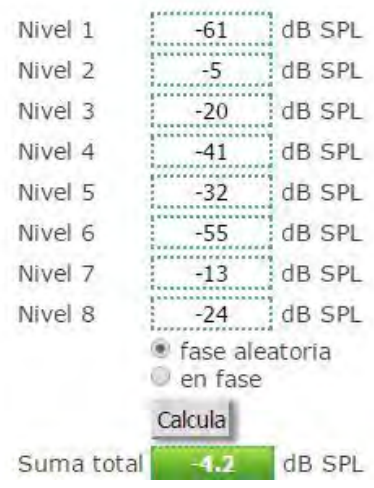

Figure 2

The sound pressure level has an average result of $-4.2 \mathrm{SPL} \mathrm{dB}$, as we can see below.

It should be noted that the random phase option is for incoherent sources (different signal in each source).

When performing the musical transcription in the melody produced by the capolin leaf blow,

it can be distinguished the use of minor and major scales, which despite being based on ancestral sounds reminds us directly to "pasillo". The results of the rythmic analysis done on Finale Demo version, show that the melody is on 68

- This fact leads to determine that despite the fact that the melody is similar to "pasillos", it is different because pasillos are not normally on 68 but on 34 . Therefore, the use of a capolin leaf is part of a Yaraví.

The tone of the melody is on Ab Major and it has anacrusis. From the fifth bar a modal shift is made by using a $\mathrm{C}$ major to pass to $\mathrm{F}$ minor, which is the relative scale of $\mathrm{Ab}$ major. This exchange is quite typical in Ecuadorian music, it can be noticed in measure two and three that there is a chromatism in the melody $(\mathrm{Eb}-\mathrm{E}-\mathrm{F})$.

For a better analysis, some chords were placed to the melody. In the first two bars the cadence IIm V I (usually used in jazz) is performed, in the third bar it passes to the $\mathrm{V}$ degree that is Eb major, in the next bar we can find a 
D natural in the melody. Therefore, an EbMaj7 chord was placed to give the melody a more contemporary sound. After Ebmaj 7 there is a $\mathrm{G} 7$ that functions as a secondary key to pass to $\mathrm{C}$ major. In the bar that belongs to $\mathrm{C}$ major the minor harmonic scale of $\mathrm{F}$ is used. It ends with a cadence V I m.

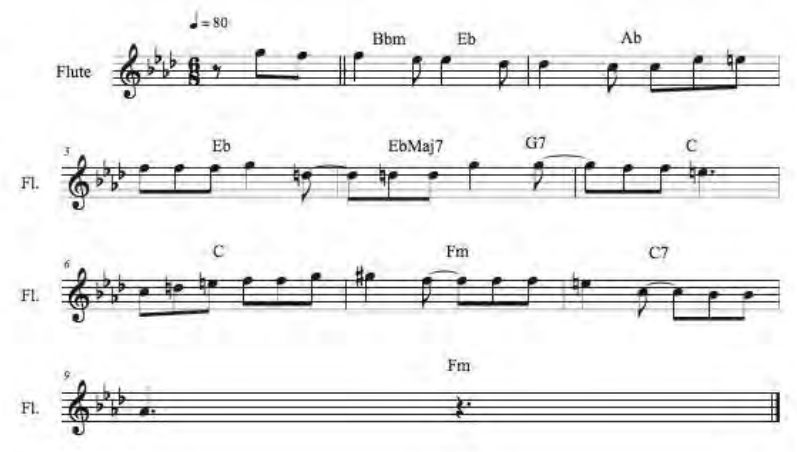

Figure 3

\section{Conclusions}

The musical expression of the Ecuadorian Andean world through the capolin leaf blow is constituted in an integrating world, in which creativity, subjectivity, technique and all the imaginary are inherited from a society that has traveled through processes of adaptation, conquest, resistance and self-determination.

The various human groups that settled in what is now the Andean Region in Ecuador have adapted themselves to their geography, similarly to capolin in the past. The capolin is of great importance not only for native peoples. Its wood and the taste of its fruit conquered the Spanish conquerors, it has conquered those who come later as well and it will continue to conquer those who come as tourists because of its musical expression. The music of the capolin leaf is a process of cultural identity resistance, whose relationship between nature and individuals are factors of sublimation and desublimation, repression and liberation. The one who emits music with the capolin leaf, starts from existential questions and establishes the mental process of gear between its subjectivity and the nature because it reconfigures its meanings. When somebody plays by heart, without any academic music knowledge, it is possible to create Andean music genres like Yaravi. Performers will be able to get melodies with anacrusis among the $\mathrm{Ab}$ majaor key or tone. From the fifth bar a modal shift is made by using $\mathrm{C}$ major to pass to the F minor, which is the relative of Ab major. In bar two and three there is a chromatism in the melody (Eb - E F)..

\section{References}

1. Agapito, E., \& Sung, I. (2005). Fitomedicina: 1100 plantas medicinales, Volumen 1. Perú: Perú.

2. Alabarces, P. (Junio de 2008). Posludio: Música popular, identidad, resistencia y tanto ruido. En V. Castro, \& M. Romo, BIODIVERSIDAD DE CHILE, PATRIMONIO Y DESAFÍOS TRADICIONES CULTURALES Y BIODIVERSIDAD (pág. 700). Obtenido de http://www.redalyc.org/comocitar.oa?id=82201207

3. Artez, I., \& Felipe, R. L. (s/f). Áreas musicales de tradición oral en América Latina - Una crítica y tentativa de reestructuración de los "cancioneros" establecidos, por Carlos Vega. Revista musical Chilena, 9-55\}

4. Asiáin, A., \& Aznárez, M. (2012). Patrimonio cultural inmaterial y adquisición/desarrollo del lenguaje: tradición discursiva y psicodinámica oral. Huarte de San Juan. Filología y Didáctica de la Lengua , 45-64.

5. Avendaño-Gómez, Á., Lira-Saade, R., Madrigal-Calle, B., García-Moya, E., Soto-Hernández, M., \& Romo de Vivar-Romo, A. (2015). MANEJO Y SÍNDROMES DE DOMESTICACIÓN DEL CAPULÍ EN COMUNIDADES DEL ESTADO DE TLAXCALA. Agrociencia,189-204.

6. Benítez, N. M., Albuja, J. I., \& Vaca, C. (2016). El Turismo Comunitario como estrategia para la visibilización y revalorización de la memoria musical los Pueblos Kichwas de Imbabura. Revista Turydes: Turismo y Desarrollo, n. 20

7. Cámara de Landa, E. (2010). EL PAPEL DE LA ETNOMUSICOLOGÍA EN EL ANALISIS DE LA MÚSICA COMO MEDIADORA INTERCULTURAL. Revista Historia Actual Online (HAOL), Núm. 23, 73-80

8. Cartagena, J. (2002). IMAGINARIO SONORO DE LOS TIEMPOS. Orquesta Insturmental de Instrumentos Nativos, OEIN, 23-27

9. Carvalho, J. J. (2003). La etnomusicología en tiempos de canibalismo musical. Una reflexión a partir de las tradiciones musicales afroamericanas. Trans. Revista Transcultural de Música $N^{\circ} 7$.

10. Castillo, J. D. (2015). La dimensión espiritual y política del canto de Enrique Males . Quito: Universidad Andina Simón Bolivar.

11. Dorunon, G. (1981). Guía para recolectar instrumentos musicales tradicionales (2 ed.). París, Francia: Editorial de la Unesco. doi:92-3-301846-6 
12. Fabre, B., De la Cuadra, P., \& Pérez de Arce, J. (2012). Antaras Aconcagua: un estudio antropológico acústico. AISTHESIS , 325-342.

13. Fernández, T. (2010). La pluma en el aire. Cuadernos de literatura del Caribe e Hispanoamérica No 12, 135-148.

14. Flores, G. (2009). "Nuestro sonido tradicional lo estamos distorsionando". Pasado y presente de la música tradicional y las bandas de viento en Tingambato, Michoacán. Revista Relaciones 120, Vol. XXX, 267-296.

15. Fresnedo-Ramírez, J., Segura, S., \& Muratalla-Lúa, A. (2011). Morphovariability of capulı'n (Prunus serotina Ehrh.) in the central-western region of Mexico from a plant genetic. Genet Resour Crop Evol , 481-495.

16. González de Pérez., M. (2005). Sobre el estudio de la música como hecho cultural. Colantropos, 1-39. Obtenido de http://www.humanas.unal.edu.co/colantropos/files/8514/5615/3641/musicaycultura.pdf

17. Hernández-Rodríguez, G., Espinosa-Solares, T., Hernández-Eugenio, G., Villa-García, M., Reyes-Trejo, B., \& GuerraRamírez, D. (2016). Influence of Polar Solutions on the Extraction of Phenolic Compounds from Capulín Fruits (Prunus serótina). Revista de la Sociedad Química de México, 73-78

18. Hormigos, J. (09 de 02 de 2010). La creación de identidades culturales a través del sonido. Comunicar(34), 91'98. doi: 11343478

19. Ibarra, C., Rojas, A., Luna, F., Rojas, J., Rivero, B., \& Rivero, J. F. (2009). VASORELAXANT CONSTITUENTS OF THE LEAVES OF PRUNUS SERONITA "CAPULÍN". Revista Latinoamericana de Química. 37/2, 164- 173

20. Isolabella, M., \& Rossano, S. (2015). ilmar la frontera: Algunas reflexiones en torno al uso del medio audiovisual en la investigación etnomusicológica. Trans. Revista Transcultural de Música núm 19, 1-16.

21. Jardow-Pedersen, M. (2003). Manual de etnomusicología, HISTORIA, RECOPILACION. México: Etnomax 2013. doi:032001-01181106290

22. Jiménez, M., Castillo, I., Azuara, E., \& Beristain, C. (2011). ANTIOXIDANT AND ANTIMICROBIAL ACTIVITY OF CAPULIN (Prunus serotina subsp capuli) EXTRACTS. Revista Mexicana de Ingeniería Química Vol. 10, No. 1, 29-37.

23. Londoño, M. (junio de 2008). Memoria colectiva y músicas locales en una perspectiva de desarrollo humano. IV Congreso Nacional de la Música, Conservatorio del Tolima. . Ibagué, Colombia. Recuperado el 30 de mayo de 2017, de http://www.conservatoriodeltolima.edu.co/images/revistas/MCP1/Musica_cultura_y_pensamiento01_F.pdf

24. Lozoya, X. (1982). Flora medicinal de México. Plantas indígenas (primera parte), México, D.F., Instituto Mexicano del Seguro Social., 80-93.

25. Mantilla, J. (2004). Las Plantas Medicinales de nuestra Madre Tierra. Cusco: Perú.

26. Martí, J. (1992). Hacia una antropología de la música. (C. -I. Fontanals, Ed.) DIGITAL.CSIC,, Anuario Musical (47) : 195225 (1992)(47). doi:v

27. Martí, J. (2009). Como el aire que respiramos; músicas ambientales en espacios de la cotidianidad. (C. Arbelos, Ed.) Música oral del Sur(8), 163-175. doi:1138-8579

28. McVaugh. (1951). Prunus serotina subsp. capuli (Cav.). Brittonia 7, 227-229.

29. Morales de la Mora, E. (2003). La etnomusicología, definición y objeto de estudio. Gaceta Universitaria.

30. Nettl, B. (2003). Reflexiones sobre el siglo XX: el estudio de los "Otros" y de nosotros como etnomusicólogos. Revista Transcultural de Música (7), 1-23.

31. Olivera, A. (2011). Patrimonio Inmaterial, Recurso Turístico y espíritu de los territorios. Revista Cuadernos de Turismo, $\mathrm{n}^{\circ} 27,663-677$.

32. Peña, M. F. (2012). Voces y sonidos de la madre tierra":jujunula makuira, la radio que fortalece el tejido social en La Guajira colombiana. Revista Anagramas Volumen 10 N 20 , 197-212.

33. Ramírez, J. (enero-abril de 2012). ¿Identidades sociomusicales rurales? (L. Girola., Ed.) Sociológica , 27(75), 157-194. doi: 0187-0173

34. Rivero-Cruz, B. (2014). Simultaneous quantification by HPLC of the phenolic compounds for the crude drug of Prunus Serotina subsp. Capuli. Pharmaceutical Biology, 1015-1020.

35. Rodríguez, Á. (22 de Febrero de 2015). El papel de la música en la construcción de una identidad durante la adolescencia ¿Dime qué escuchas y te diré quién eres? doi:2254-3643

36. Steingress, G. (2006). El caos creativo: fiesta y música como objetos de deconstrucción y hermenéutica profunda. Una propuesta

sociológica. (T. Rojo, Ed.) Revista Andaluza de Ciencias Sociales(6), 43'-75. doi: 1696-0270

37. Veladiz, J. (2009). Musicoterapia con instrumentos precolombinos. Antropología, Boletín Oficial del Instituto Nacional de Antropología e Historia, 89-91 